\title{
Integrated regional vulnerability assessment of government services to climate change.
}

\author{
Brent Jacobs, Christopher Lee, David O'Toole and Katie Vines
}

Corresponding Author's Email: Brent.Jacobs@uts.edu.au

\section{Structured Abstract:}

\section{Purpose}

This paper describes the conduct and outcomes of an Integrated Assessment of the vulnerability to climate change of government service provision at regional scale in New South Wales, Australia .The assessment was co-designed with regional public sector managers to address their needs for an improved understanding of regional vulnerabilities to climate change and variability.

\section{Design/methodology/approach}

The study employed Integrated Assessment of climate change impacts through a complex adaptive systems approach incorporating social learning and stakeholder-led research processes. Workshops were conducted with stakeholders from NSW government agencies, State-owned corporations and local governments representing the tourism, water, primary industries, human settlements, emergency management, human health, infrastructure, and natural landscapes sectors. Participants used regional socioeconomic profiling and climate projections to consider the impacts on and the need to adapt community service provision to future climate.

\section{Findings}

Many sectors are currently experiencing difficulty coping with changes in regional demographics and structural adjustment in the economy. Climate change will result in further impacts on already vulnerable systems in the forms of resource conflicts between expanded human settlements, the infrastructure that supports them and the environment (particularly for water), increased energy costs and declining agricultural production and food security.

\section{Originality/value}

This paper describes the application of meta-analysis in climate change policy research and frames climate change as a problem of environmental pollution and an issue of development and social equity

\section{Keywords:}

Integrated assessment, climate change vulnerability and adaptation, regional service provision, public sector, Australia

\section{About the authors}

Dr Brent Jacobs is Research Director in the natural resources and ecosystems theme at the Institute for Sustainable Futures, The University of Technology, Sydney. He has worked as an academic in agricultural science at the University of Sydney and the University of the South Pacific. Brent has over a decade of experience as a Senior Project Manager with the NSW Government in natural resource and structural adjustment policy and programs.

Christopher Lee is currently the Manager of Impacts and Adaptation in the NSW Office of Environment and Heritage and leads NSW policy development in Climate Change Adaptation.

David O'Toole has over 10 years' of service with the NSW Government in environmental management and biodiversity conservation policy. For the past 3 years He worked as a Senior Policy Officer in the Impacts 
and Adaptation team of the NSW Office of Environment and Heritage, focussing on regional vulnerability assessments, and adaptation programs for the Emergency Management, Health and Infrastructure sectors.

Katie Vines is a Senior Policy Officer in the Impacts and Adaptation team of the NSW Office of Environment and Heritage. Katie's work focuses on understanding regional vulnerability and developing adaptation responses.

\section{Acknowledgments:}

The authors gratefully acknowledge the assistance of Ros Chivers, Gary Allen and members of the South East Regional Managers Network in organising workshops. In addition we thank the public sector employees from the SE Region of NSW for their willingness to share their knowledge of the region. This study was funded by the NSW Office of Environment and Heritage. 


\section{Introduction}

Climate change is recognised as a multidimensional, cross-scale, cross-governance issue that impacts to varying extent on vulnerable components of complex social-ecological systems (Cash et al., 2006; Hartel and Pearman, 2010; Ribot, 1995; Scarlett, 2011; Vignola et al., 2009). Ison (2010) advocates for the utility of systemic approaches to deal with the complexity of climate change and the syndrome of accompanying problems facing society, which includes 'peak resources', rising population and consumerism, changing demographics, and over exploitation of the environment and the ecosystem services it provides.

Governments have a number of roles to play in responding to the threat posed by climate change. These roles encompass the need to adapt its own programs and activities, to regulate to reduce community vulnerability and to build the adaptive capacity of the community to facilitate adaptive responses (Brooks et al., 2009). Fankhauser et al. (1999) suggested that because of the long time horizon and prevailing uncertainties about climate change, the best strategy would be to increase the flexibility of systems to function under a wider range of climatic conditions. They contend that the main role for government is to provide the correct legal, regulatory and socio-economic environment to support autonomous adaptation. Such action would require the flexibility to change behaviour, policy, law, politics and customs, which may constrain adaptive responses. However, governments traditionally operate within policy silos often linked to specific legislative frameworks (OECD, 2010; Pelling, 2011). This mode of operation will need to change to respond effectively to the system-wide impacts of changing climate that span administrative and geographical boundaries. The difficulty for government, in the first instance, is in developing and implementing processes that are able to inform policy by identifying systemic vulnerabilities and potential actions to address them.

Vulnerability has been described as a bridge that connects the physical impacts of climate to adaptations in social-ecological systems (Malone and Engle, 2011). The IPCC defines vulnerability as the degree to which a system is susceptible to, and unable to cope with, the adverse effects of climate change, including climate variability and extremes (IPCC, 2008). Vulnerability is generally conceptualised as a combination of the geographical and temporal proximity to a hazard (exposure) and the propensity for exposure to result in harm (sensitivity); exposure and or sensitivity can be moderated through system adaptation (Pelling, 2011). Cultural dimensions, such as risk perception mediated through personal experience of a hazard and trust in authorities (Wachinger et al., 2012), expand the definition of vulnerability to include the preparedness to act and influence personal lifestyle choices, voting behaviour, and willingness to support climate change policy initiatives (Bostrom et al., 1994).

Vulnerability assessment offers a method by which current system functioning can be examined in light of increased future variability in climate. Malone and Engle (2011) describe a number of aims of vulnerability assessment including improving adaptation planning, unveiling social injustices, highlighting the ramifications of inaction on climate change, improving basic scientific understanding, allocation of funding to a group of countries, identification of vulnerability 'hot spots', or simply to begin a continuing dialog with decision-makers and stakeholders about climate change and vulnerability issues. Smit and Wandel (2006) describe 4 types of vulnerability-adaptation assessment for climate change:

1. Analyses designed to focus on the moderation or mitigation of modelled impacts of climate change scenarios by assumed adaptations.

2. Analyses that rate or rank potential adaptations usually without investigating the policy and decisionmaking processes through which adaptation measures are undertaken.

3. Top-down, science-led construction of indices of relative vulnerability (or adaptive capacity) at a range of scales to facilitate comparative evaluation. The determinants or drivers of adaptive capacity 
and vulnerability, and the policy and decision-making processes that deal with the conditions that can alter adaptive capacity and vulnerability, are rarely a focus of such studies.

4. Participatory analyses that focus on tailoring adaptive measures or practices for a particular region or community to identify means of implementing policies and decision-making processes to reduce vulnerability or enhance adaptive capacity.

Theoretical and practical considerations narrow the choice of assessment method from those listed above. From a theoretical standpoint, application of learning from research on complex systems indicates that analyses dependent on purely reductionist approaches may be problematical. Such approaches fail to account for many of the characteristics of complex systems such as self-organisation, emergent properties and multiple identities across spatial or temporal scales, nonlinear system behaviours, self-entailment and social or other interactions that affect system attributes (Giampietro, 2002; Gomiero et al., 2006; Melanson, 1996; Milne, 1998; Rindfuss et al., 2008). From the practical view point of informing adaptation policy, Patt et al .(2005) suggest system complexity, the difficulty of testing empirically the proposed interactions between different vulnerability drivers, and the uncertainty of making robust predictions about future adaptive capacity over extended time scales as shortcomings of assessment methods relying on vulnerability modelling. The issue of uncertainty, in particular, often fosters delay among policy makers seeking optimal decision-making predicated on the predictive accuracy of climate models and under pressure from climate sceptics for 'better climate science' (Adger et al., 2009; Nerlich, 2010; Reibsame, 1990).

Integrated Assessment (IA) has been proposed and is increasingly used as a structured process of dealing with complex issues, using knowledge from various scientific disciplines and/or stakeholders, such that integrated insights are made available to decision makers (Rotmans, 1998). While this definition suggests that the involvement of stakeholders is optional, many authors (for example, de la Vega-Leinert and Schroter, 2009; Smit and Wandel, 2006; Rainer, 2010; Rainer and Malone, 1998) have argued that the engagement of non-scientific knowledge, values and preferences into vulnerability assessments through various forms of stakeholder participation will:

- allow for the recognition of multiple stimuli beyond those related to climate, to include political, cultural, economic, institutional and technological forces;

- implicitly recognize the dynamic nature of exposures, sensitivities and adaptive capacities over time;

- recognize that sources of vulnerability function across scales from the individual to the global;

- encourage social learning, collaboration, conflict resolution, long-term visioning, and joint planning among participants; and

- improve the quality of assessments by giving access to practical knowledge and experience, and to a wider range of perspectives and options than purely top-down, science-led techniques.

Moreover, Giampietro (2002) argues that where indeterminacy or complexity are characteristics of the system, as in social-ecological systems, IA based on transdiciplinary analyses and participatory techniques allows 'procedural rationality' to be established ensuring human perceptions and preferences are considered as part of policy formulation. Collins and Evans (2002) attempted to separate the need for legitimacy from the over-extension of participation in decision making where science and technology intersect with the political domain, such as in climate change vulnerability and adaptation. They classify climate change science as a reflexive historical science because it is based on unique historical trends (long term weather forecasting), rather than repeatable laboratory tests, and the input variables to decision making include the outcomes of political and ethical debates in the community. Although contentious (Janasoff, 2003), they argued that participation should be based on a normative theory of expertise where by an appropriate 
balance of contributory, interactional and referred expertise would depend on decisions in different kinds of science and in different kinds of cultural enterprise.

Rainer (2010) argues that better adaptation to current conditions and to anticipated future climate should be designed and implemented at the lowest feasible levels of organisation that reduce vulnerability to climate change in the short and medium term. IA conducted at local or regional scale has advantages over global approaches because more reliable data are available locally, system complexity is more constrained and more manageable, communication is more effective because of greater political interest, and opportunities for testing reciprocal relationships among processes across scales become possible (Costanza and Tognetti in Rotmans, 1998). However, despite considerable research into downscaling (Fowler et al., 2007) difficulties persist in using geographically-explicit climate information in decision-making at regional scale (Weaver et al., 2013), which can raise unrealistic expectations of outcomes in assessments involving stakeholders (Rotmans, 1998).

Tacit knowledge is the personal knowledge resident within the mind, behaviour and perceptions of individuals. It includes skills, experiences, insight, intuition and judgment (Busch 2004). It is typically shared through discussion, stories, analogies and person-to-person interaction making it difficult to capture or represent in explicit form (Gertler, 2003). Local stakeholders are the custodians of context-specific tacit knowledge about the local impacts of broad scale change on the complex systems in which they are embedded (for example Quenton Grafton, 2010). IA provides a vehicle through which local tacit knowledge can be externalised, shared and codified to encourage the establishment of new knowledge networks, the sharing of cognitive frames and the potential for improvisation (Augier and Vendelo, 1999; Nonaka and von Krogh, 2009). For governments developing policy under the uncertainty of future climate, flexible learning and experimentation are essential in promoting adaptive responses and the formation of networks among individuals across scales in the organization become a central source of internal stability (Augier and Vendelo, 1999). The knowledge generated through such processes is critical to decision making because policy makers' information about actual institutional performance is very limited, rarely field based, and drawn mainly from interested parties (Fox, 2001).

In this paper we describe the conduct and outcomes of IA of the vulnerability to climate change of government service provision at regional scale in New South Wales, Australia. Rather than being 'supplydriven' (Rotmans, 1998), the assessment approach was co-designed with regional public sector managers in an attempt to address their needs for an improved understanding of existing regional vulnerabilities that would likely be amplified by medium-term climate change and variability. In keeping with contemporary understanding of vulnerability assessment, the approach was sector-based and participatory (including both scientists and local 'experts'). The purpose of the assessment was to integrate socioeconomic and biophysical information with participants' tacit knowledge of local conditions to inform decisions about the need for government to adapt to future climate and provide input to a subsequent adaptation planning process.

\section{The Integrated Regional Vulnerability Assessment (IRVA) Process}

The IRVA was adapted from the method developed by Li (2010) for assessment of climate change impacts on local scale urban systems. This method was chosen because it facilitated IA of climate change impacts through a complex adaptive systems approach and incorporated social learning and stakeholder-led research processes, which ensured the findings were relevant to those responsible for policy making and management. Li's approach was augmented with a detailed analysis of adaptive capacity drawing on the participatory workshop process of Brown et al. (2010) designed to identify factors that enabled and 
constrained adaptation of natural resource managers leading to adoption of improved management practices (Leith et al., 2012).

The study area was the South East region of NSW. This region encompasses an administrative state planning region which is serviced by a Regional Managers Network (RMN) comprised of cross-agency decision makers and program managers. The South East covers an area of more than 60,000 square kilometres of the south-eastern corner of NSW (Figure 1) and includes a broad spectrum of climatic zones with diverse topography and demography.
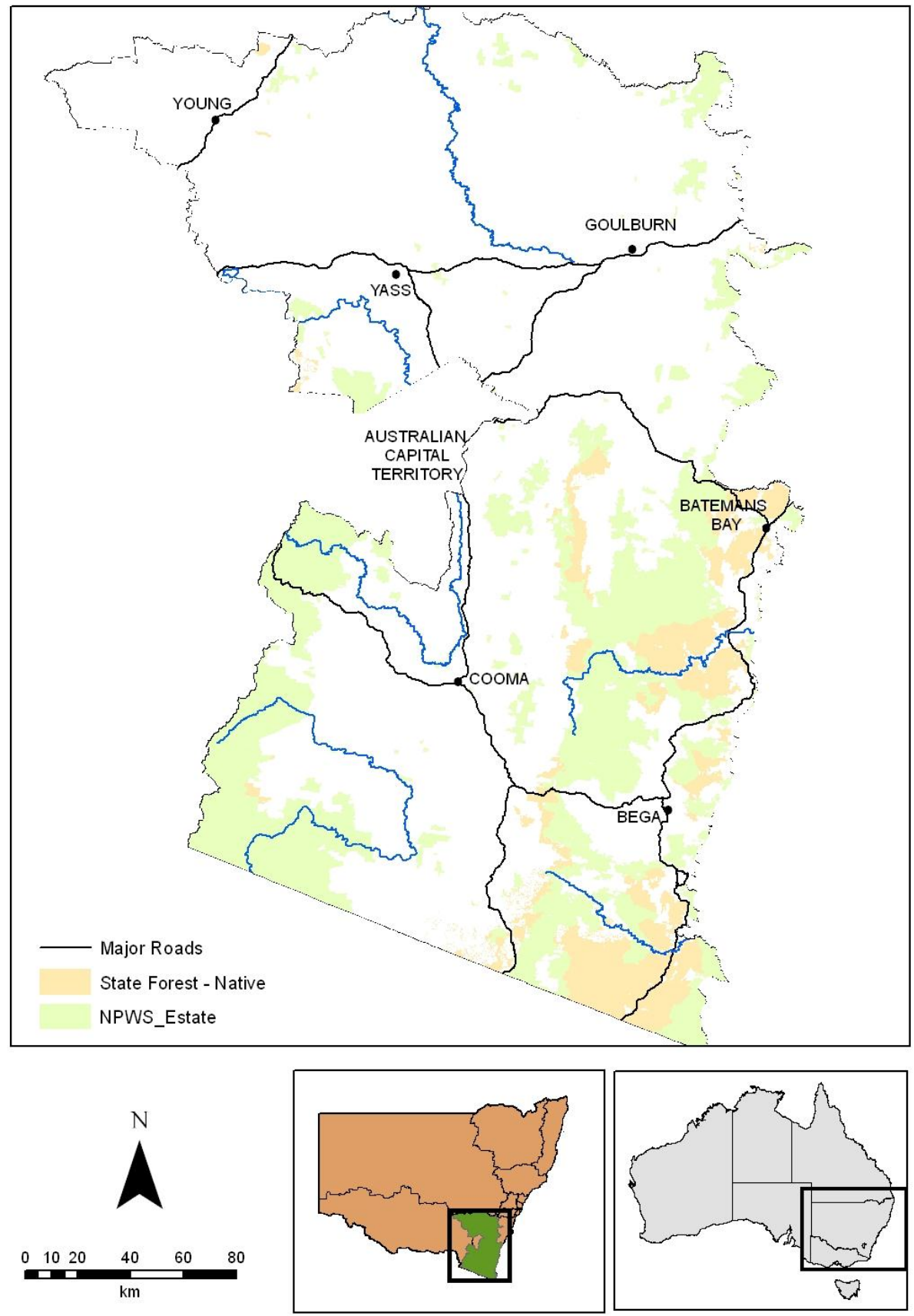

Figure 1. The study area is the NSW South East State Plan Region. A network of regional government managers coordinated by the NSW Department of Premier and Cabinet, oversees regional delivery of state government initiatives. 
The IRVA consisted of the following stages:

1. IRVA governance - establishment of a steering committee comprising regional representatives from a number of key government agencies to provide project governance and help to engage regional stakeholders. Eight priority sectors that reflect planning and governance structures within the region were selected for participation: tourism, water, primary industries, human settlements, emergency management, human health, infrastructure, and natural landscapes. Stakeholders from NSW government agencies, State-owned corporations and local governments were invited to participate from each sector. In addition, representatives from the Australian Capital Territory Government (a neighbouring jurisdiction encompassing the city of Canberra) were invited to attend as observers. In total, the workshops involved more than 160 participants (Table 1).

Table 1: List of participating agencies/organisations for SE IRVA workshops.

\begin{tabular}{|c|c|}
\hline Sector (no.) & Agencies/organisations \\
\hline $\begin{array}{l}\text { Human } \\
\text { health } \\
(21)\end{array}$ & $\begin{array}{l}\text { NSW Government: Health (Greater Southern Area Health Service, } \\
\text { Greater Western Area Health Service), Human Services (Ageing } \\
\text { Disability and Home Care), } \\
\text { ACT Government: Health }\end{array}$ \\
\hline $\begin{array}{l}\text { Tourism } \\
\text { (12) }\end{array}$ & $\begin{array}{l}\text { Australian Government: Regional Development Australia } \\
\text { NSW Government: Industry \& Investment (Tourism), Environment } \\
\text { Climate Change Energy and Water (Parks) } \\
\text { Local Government: Snowy River, Bombala, Eurobodalla } \\
\text { ACT Government: Environment Climate Change Energy and Water }\end{array}$ \\
\hline $\begin{array}{l}\text { Human } \\
\text { Settlements } \\
(16)\end{array}$ & $\begin{array}{l}\text { NSW Government: Planning, Housing } \\
\text { Local Government: Cooma-Monaro, Eurobodalla, Goulburn- } \\
\text { Mulwaree, Harden, Queanbeyan City, Yass Valley Council, Young } \\
\text { Regional Councils } \\
\text { ACT Government: Planning \& Land Authority }\end{array}$ \\
\hline $\begin{array}{l}\text { Infrastructure } \\
\text { (14) }\end{array}$ & $\begin{array}{l}\text { Australian Government: Attorney-General's } \\
\text { NSW Government: Roads and Transport Authority } \\
\text { Local Government: Cooma-Monaro, Snowy River Yass Valley, and } \\
\text { Young Regional Councils } \\
\text { ACT Government: Education, Chief Ministry Directorate } \\
\text { Energy corporation: Country Energy }\end{array}$ \\
\hline $\begin{array}{l}\text { Primary } \\
\text { Industries } \\
\text { (22) }\end{array}$ & $\begin{array}{l}\text { NSW Government: Industry \& Investment; Lachlan, } \\
\text { Murrumbidgee, Southern Rivers, and Hawkesbury-Nepean } \\
\text { Catchment Management Authorities (CMA) } \\
\text { Office of Water (NoW) } \\
\text { ACT Government: Environment Climate Change Energy and Water }\end{array}$ \\
\hline $\begin{array}{l}\text { Emergency } \\
\text { Management } \\
(26)\end{array}$ & $\begin{array}{l}\text { NSW Government: Police, Rural Fire Service, Fire Brigades, } \\
\text { Ambulance Service, State Emergency Service, Premier and Cabinet, } \\
\text { Industry \& Investment, Public Works, Transport. } \\
\text { Local Government: Bega Valley, Goulburn-Mulwaree, Snowy River, } \\
\text { Yass Valley Councils } \\
\text { ACT Government: Environment Climate Change Energy and Water }\end{array}$ \\
\hline $\begin{array}{l}\text { Landscapes } \\
\& \\
\text { Ecosystems } \\
(28)\end{array}$ & $\begin{array}{l}\text { NSW Government: Office of Water, Environment Climate Change } \\
\text { and Water, Hawkesbury-Nepean, Lachlan, Southern Rivers, } \\
\text { Murrumbidgee CMA } \\
\text { Local Government: Bega Valley, Eurobodalla, Goulburn-Mulwaree, } \\
\text { Palerang, Yass Valley Councils } \\
\text { ACT Government: Environment Climate Change Energy and Water }\end{array}$ \\
\hline $\begin{array}{l}\text { Water } \\
(25)\end{array}$ & $\begin{array}{l}\text { NSW Government: Office of Water, Industry \& Investment, Southern } \\
\text { Rivers CMA }\end{array}$ \\
\hline
\end{tabular}




\begin{tabular}{|l|l|}
\hline & $\begin{array}{l}\text { Local Government: Cooma-Monaro, Queanbeyan, Snowy River, } \\
\text { Yass Valley, Young Regional Councils } \\
\text { ACT Government: Environment Climate Change Energy and Water, } \\
\text { ActewAGL (energy, gas water supply and distribution) }\end{array}$ \\
\hline $\begin{array}{l}\text { Integration } \\
(50)\end{array}$ & $\begin{array}{l}\text { Participants drawn from previous sector workshops covering NSW, } \\
\text { ACT and Local Governments. }\end{array}$ \\
\hline
\end{tabular}

2. Collection and synthesis of regional climate change and socio-economic information based primarily on the NSW Climate Impact Profile (DECCW, 2010; Table 2) and census data (ABS, 2008) respectively. This information was supplemented with regional socio-economic research, demographic data and other peer reviewed scientific research where available.

Table 2. A qualitative summary of the likely impacts of climate change on the South East Region included as background information to the IRVA (DECCW 2010)

By 2050, the climate of the South East Region:

- Is virtually certain to be hotter, with a likely rainfall increase in summer and decrease in winter. Snowfall is likely to decrease. However, changes in weather patterns that cannot be resolved by the climate models mean that rainfall in coastal parts of the region is difficult to simulate.

- Run-off and stream flow are likely to decrease in spring and winter, particularly in the west, and increase during summer.

- Sea level is virtually certain to continue to rise.

- The rate of erosion is likely to increase on some soils. Coastal agricultural soils are likely to be inundated and acidification is likely to increase.

- Sea level rise coupled with increased flooding is virtually certain to pose an increased risk to property and infrastructure in coastal areas. Developments near coastal lakes and estuary entrances and on coastal floodplains are vulnerable.

- Widespread changes to some natural ecosystems are very likely. Those most at risk are alpine ecosystems, low-lying coastal ecosystems and those sensitive to fire.

3. Introduction to the IRVA process via a cross-agency workshop with participants drawn from the eight participating sectors. The purpose of the workshop was to introduce a systems thinking approach and to start consideration of impacts and inter-relationships between sectors.

4. Assessment of sectoral impacts and adaptive capacity via separate sector workshops. Participants were asked to consider impacts over the next 40 years (that is, until the year 2050), the potential for interaction or 'flow-on' of impacts among sectors, and factors that might act to facilitate or impede the capacity of sectors to adapt to those impacts. Participant-constructed influence diagrams were used to provide an intuitive framework in which to examine climate change as perceived by regional service providers and to incorporate their tacit knowledge of local conditions (Loria, 2006; Shachter, 1986). After consideration of sectoral impact pathways, workshops shifted focus to a discussion of adaptive capacity. Given what participants now knew were the likely effects of climate change in the SE region, three questions were posed:

- What must change (adaptive capacity indicators) to service the community and why?

- What is needed to enable change? (capacity constraints to action) 
- Where is change needed most/least? (spatial heterogeneity of adaptation).

A framework of five capitals (Table 3) (Ellis, 2000) was used to identify qualitative indicators of adaptive capacity and provide a unifying concept by which narratives of change could be analysed across sectors at a range of scales.

Table 3. Description of the five capitals framework (after Ellis, 2000).

\begin{tabular}{|c|l|}
\hline Capital & \multicolumn{1}{c|}{ Description } \\
\hline Human & $\begin{array}{l}\text { The skills, health and education of individuals that contribute to the productivity of } \\
\text { labour and capacity to respond to climate. }\end{array}$ \\
\hline Social & $\begin{array}{l}\text { Reciprocal claims on others by virtue of social relationships, the close social } \\
\text { bonds that facilitate cooperative action and the social bridging, and linking via } \\
\text { which ideas and resources are accessed. }\end{array}$ \\
\hline Natural & $\begin{array}{l}\text { The productivity of land, and actions to sustain productivity, as well as the water } \\
\text { and biological resources from which livelihoods are derived. }\end{array}$ \\
\hline Physical & $\begin{array}{l}\text { Capital items produced by economic activity from other types of capital that can } \\
\text { include infrastructure, equipment and improvements in genetic resources (crops, } \\
\text { livestock). }\end{array}$ \\
\hline Financial & $\begin{array}{l}\text { The level, variability and diversity of income sources, and access to other financial } \\
\text { resources (credit and savings) that together contribute to wealth. }\end{array}$ \\
\hline
\end{tabular}

5. Integration of assessment results through a workshop involving approximately 50 participants from each of the sectors under study to discuss the cross-sectoral impacts identified at each of the sectoral workshops and a consolidated list of actions to address vulnerability, and provide an holistic assessment of the region's vulnerability to climate change. This step offers an opportunity for reflection and organisational learning (Loverde, 2005) to ensure individual sectors appreciate the potential for maladaptive outcomes through unilateral action.

6. Identification of key regional vulnerabilities through thematic analysis of qualitative information collected at each of the workshops. Regional vulnerabilities and associated actions were viewed as providing input to a future process of detailed adaptation planning for the region using an Assumption-Based Planning approach (Walker et al., 2013).

The IRVA produced a large qualitative dataset. The results presented below will focus on the integrated aspects of regional vulnerability and adaptive capacity rather than findings for individual sectors (available on line at: www.environment.nsw.gov.au/climatechange/irvadescription.htm/).

\section{Results}

\section{Sectoral Impact Diagrams}

In light of the SE Region climate projections and the socio-economic synthesis report, at each sector workshop participants constructed influence diagrams to illustrate impact pathways and influence relationships stemming from each of the major climate variables (Figure 2). 


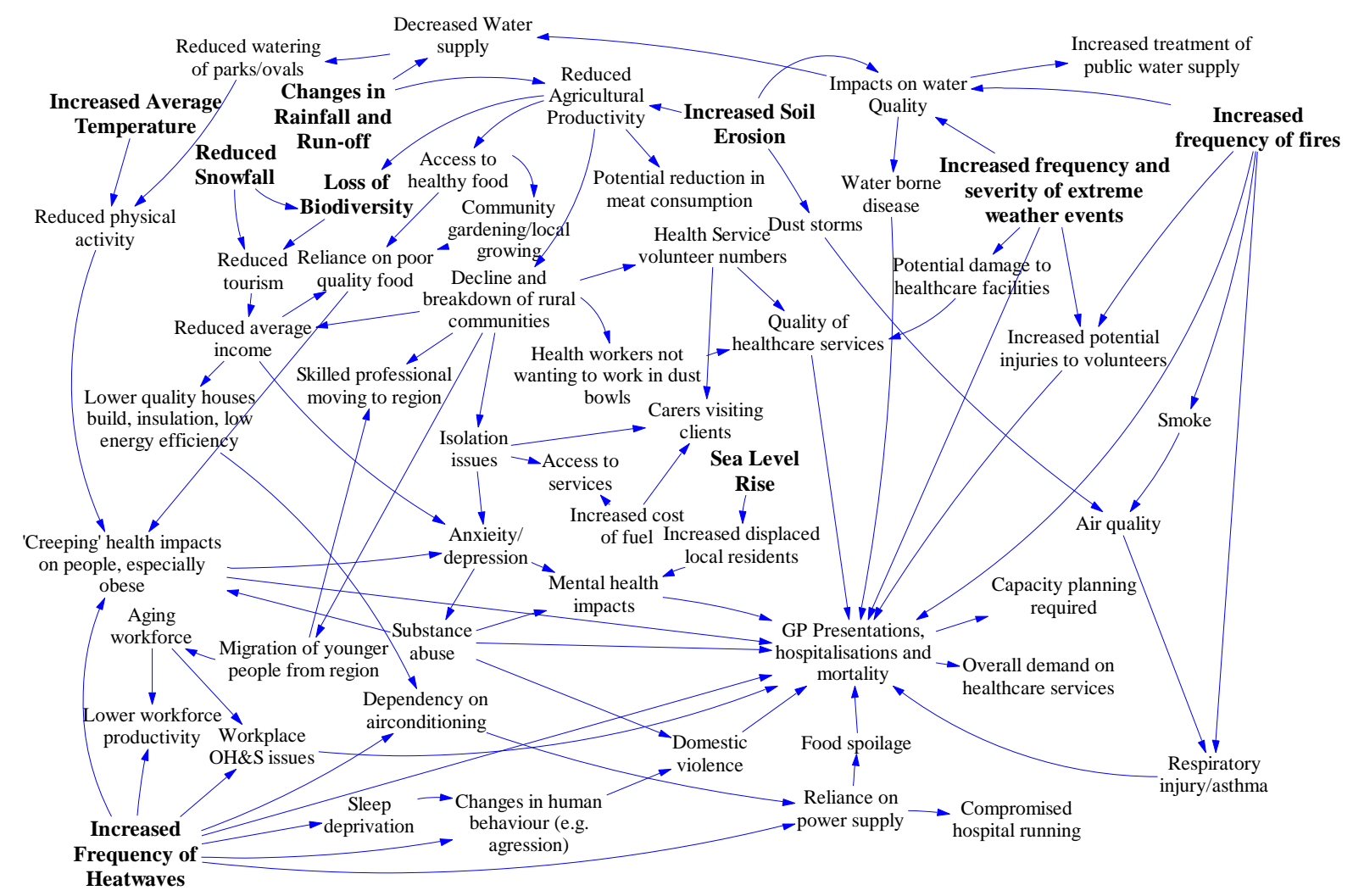

Figure 2: Influence diagram describing impact pathways for the health sector in South East NSW.

These diagrams allowed three types of impacts to be identified along impact pathways. Direct impacts were those that were directly attributable to future climate change and appear on impact pathways in close proximity to climate variables. Indirect impacts, those not immediately due to climate change but owing to both climate change and external regional drivers, appeared at more distal locations on impact pathways. For example, participants at the health sector workshop identified higher average temperatures leading to an increase in the frequency and intensity of bushfires as posing a direct risk to the health of the community and emergency services volunteers. Further along this pathway, these direct risks to health led to potential indirect impacts on the region's healthcare services and resources through greater need for general practitioner visits and hospital emergency ward presentations.

In addition to direct and indirect impacts, cross-sectoral interdependencies were also identified as arising from common and flow-on impacts. For example, for the health sector, the impact pathway resulting from the effects of higher temperatures on reduced snowfall in alpine areas of the South East, could be traced to a loss of alpine tourism potentially damaging local economies and limiting the number of healthcare volunteers available to assist in declining rural towns.

\section{Adaptive Capacity}

The five capitals (human, social, natural, physical and financial) provided a framework for discussion of adaptive capacity, which allowed regional integration across sectors but accommodated the varying contextual nature of sectoral capacity. The discussion not only provided an assessment of adaptive capacity of each sector and identified factors that constrained capacity to adapt; it also provided guidance on the scale and responsibility (local, regional, and/or state/national) at which action was needed to remove capacity constraints.

In total, the sector workshops identified about 130 indicators of adaptive capacity. The total number of 
indicators assigned to each capital was relatively evenly distributed (Figure 3). However, within each capital, the assignment of responsibility for action to address capacity constraints varied considerably. For human, natural and physical capitals, responsibility for action tended to favour the regional scale. For social capital responsibility for action tended to reside at local and regional, rather than national scale. However, most strikingly, action to remove constraints on financial capital was seen as primarily lying outside local or regional control focussing on the state/national scale.

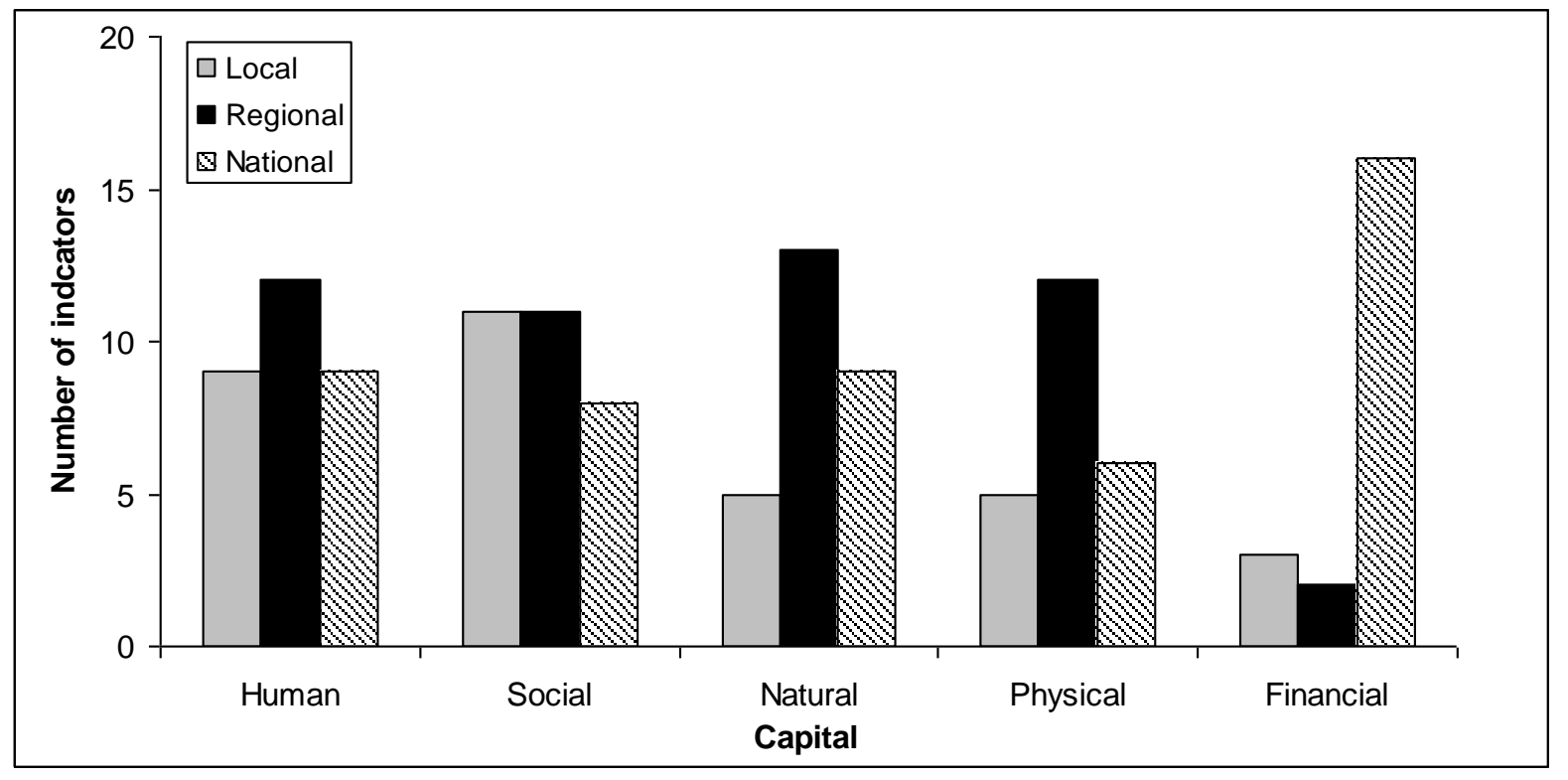

Figure 3. Pooled analysis of the number of indicators of adaptive capacity from all sector workshops categorised by capital and scale of responsibility for action.

Each indicator of adaptive capacity was associated with a brief narrative of its significance. For example, under human capital, the emergency management sector identified changed regional demographics as an indicator of that sector's capacity to adapt to climate change associated with the following narrative:

The South East region has an aging population and it is expected that local communities will be increasingly less able to care for themselves in the future making the population more vulnerable to climate change. In addition, sea/tree changers generally have relocated from well serviced urban locations and consequently have higher expectations of service provision but may be unwilling to, or ineffective in, contributing to emergency management. It was felt that the sector needed to communicate better with the community on emergency management and that an education program would increase individual awareness and resilience in coping with emergency situations that might arise from increased climate variability and change.

Responsibility for action to address capacity constraints in emergency management associated with demographic change was considered to lie primarily with state and national governments in developing a community education program that could serve the needs of regions in similar circumstances throughout Australia.

Not surprisingly, themes were identified within the descriptors of a number of indicators that were common to several sectors. For example, aging (community and workforce) was identified as a constraint to adaptation by the agriculture, human settlements, and infrastructure workshops. These common themes allowed connections between the sectors to be explored in relation to region-scale vulnerability, and the potential for change in one sector to lead to positive or maladaptive outcomes for related sectors (Figure 4). 
For example, the natural landscapes sector was linked to the tourism sector because it provides and maintains relatively undeveloped coast, native vegetation, healthy water ways, and public reserves that are a magnet for tourists to the SE Region. The provision of cost effective transport options (largely based on private vehicles) is required to maintain the viability of regional tourism, and links this sector to the infrastructure sector. The construction and maintenance of transport corridors to support regional industries, including tourism, by the infrastructure sector is linked to the natural landscapes sector because transport infrastructure can impact both the function and visual amenity of landscapes. Thereby, adaptation to climate change within one sector may result in positive or negative outcomes for several related sectors downstream and serves to illustrate the need for regional climate change policy to be integrated to avoid potential maladaptation.

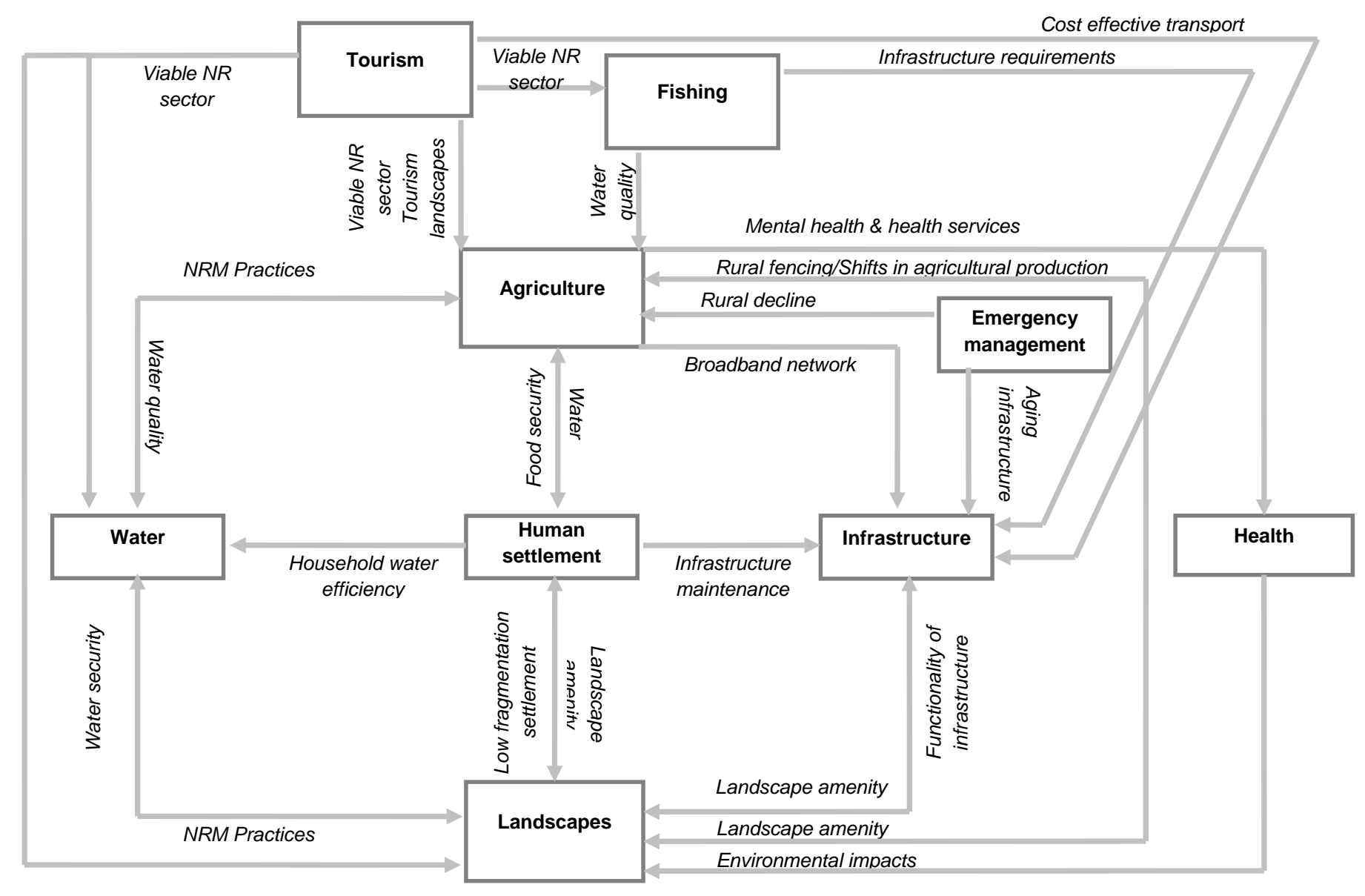

Figure 4: Interconnections between sectors shown as a network diagram.

\section{Regional Vulnerability}

Six themes of regional vulnerability were identified: competition for water; regional economic sustainability; land use change; ecosystem function and services; regional infrastructure; and regional community. Table 4 provides an overview of the major factors contributing to each vulnerability theme, the constraints on adaptation and some suggested actions that, through further discussion, might improve regional adaptive capacity. 
Table 4: Integration of data across sectors yielded six key themes of regional vulnerability, the major factors contributing to each theme, constraints to adaptation and actions to improve regional adaptive capacity.

\begin{tabular}{|c|c|c|}
\hline Regional Vulnerability & Adaptive constraints & Suggested actions \\
\hline \multicolumn{3}{|l|}{ Competition for water } \\
\hline $\begin{array}{l}\text { - Water security for small- } \\
\text { towns } \\
\text { - Local government service } \\
\text { provision } \\
\text { - Farm productivity } \\
\text { - Hydro-electric power } \\
\text { generation }\end{array}$ & $\begin{array}{l}\text { - Undervalued water } \\
\text { resources } \\
\text { - Poorly integrated water } \\
\text { management } \\
\text { - Lack of incentives for } \\
\text { on-farm water efficiency }\end{array}$ & $\begin{array}{l}\text { - Value water appropriately, including, better acknowledging water's amenity value } \\
\text { - Incentivise best practice land management for water quality } \\
\text { - Match water quality to end use in urban areas } \\
\text { - Network regional water supplies and integrate the management of water from } \\
\text { various sources } \\
\text { - Regulate unregulated rivers and ground water sources, and map all aquifers } \\
\text { - Drive collaboration between state agencies and local governments }\end{array}$ \\
\hline \multicolumn{3}{|l|}{ Economic sustainability } \\
\hline $\begin{array}{l}\text { - Viability of agriculture and } \\
\text { alpine tourism } \\
\text { - Dependence of service, } \\
\text { manufacturing and } \\
\text { processing industries on } \\
\text { agriculture } \\
\text { - Dependence of tourism and } \\
\text { agriculture on fuel prices. } \\
\text { - Natural assets, coastal } \\
\text { tourism and critical } \\
\text { infrastructure to extreme } \\
\text { weather events }\end{array}$ & $\begin{array}{l}\text { - Land prices and } \\
\text { pressure for subdivision } \\
\text { farms } \\
\text { - Emigration of youth and } \\
\text { aging work force } \\
\text { - Uncertainty surrounding } \\
\text { climate and agricultural } \\
\text { policy } \\
\text { - Cost of insuring farm } \\
\text { and other assets }\end{array}$ & $\begin{array}{l}\text { - Identify 'tipping points' for business closure to avoid cascading effects of loss of } \\
\text { services on local and regional economies } \\
\text { - Remove barriers to ongoing processes of structural adjustment in agriculture } \\
\text { - Assist farmers to take advantage of opportunities arising from national mitigation } \\
\text { policies } \\
\text { - Change focus to whole-of-season tourism to promote and market regional diversity } \\
\text { and broaden regional appeal in Alpine and Coastal areas. } \\
\text { - Merge some core council functions to pool resources to compete in the skilled } \\
\text { workforce market } \\
\text { - Incentives to increase the intake and retention of workforce in the region } \\
\text { - Improve communication of NRM to the community and elected local government } \\
\text { representatives } \\
\text { lnvest in leadership training for community and provide opportunities to employ } \\
\text { leadership skills }\end{array}$ \\
\hline \multicolumn{3}{|l|}{ Land use change } \\
\hline $\begin{array}{l}\text { - Dependence of small rural } \\
\text { towns on farming } \\
\text { - Local fresh food security } \\
\text { /supply } \\
\text { - Vegetation management on }\end{array}$ & $\begin{array}{l}\text { - High land values } \\
\text { - Current subdivision } \\
\text { planning tools } \\
\text { - Large standard housing } \\
\text { models }\end{array}$ & $\begin{array}{l}\text { - Improve communication and engagement in planning between levels of } \\
\text { government on NRM } \\
\text { - Review minimum lot size planning to account for primary production for a given } \\
\text { locality. } \\
\text { - Better incorporate natural hazard risk and emergency management into land use }\end{array}$ \\
\hline
\end{tabular}




\begin{tabular}{|c|c|c|}
\hline $\begin{array}{l}\text { private land and for bush fire } \\
\text { hazard reduction } \\
\text { - Groundwater aquifers from } \\
\text { access through rural } \\
\text { subdivision } \\
\text { - Construction and } \\
\text { maintenance of new } \\
\text { infrastructure for rural } \\
\text { residential subdivision } \\
\text { - Development on hazard } \\
\text { exposed land } \\
\text { - Rural visual amenity }\end{array}$ & $\begin{array}{l}\text { - Lack of options for } \\
\text { farmer retirement }\end{array}$ & $\begin{array}{l}\text { planning and infrastructure construction. } \\
\text { - Raise regional awareness of climate change on food resources and food security } \\
\text { to assist in holistic planning for the region } \\
\text { - Enhance capacity to undertake planning that bridges natural and social capitals at } \\
\text { appropriate scales } \\
\text { - Commission research into the impacts of rural residential development on the } \\
\text { region's natural resources and primary production } \\
\text { - Create regional and local development scenarios to assist in planning } \\
\text { - Ensure climate change impacts and adaptation measures are incorporated into 5- } \\
\text { yearly reviews of major regional planning strategies. }\end{array}$ \\
\hline \multicolumn{3}{|c|}{ Ecosystem function and services } \\
\hline $\begin{array}{l}\text { - Natural resource-based } \\
\text { industries } \\
\text { - NRM funding and investment }\end{array}$ & $\begin{array}{l}\text { - Economic pressures on } \\
\text { agriculture } \\
\text { - Poor configuration of } \\
\text { rural fencing } \\
\text { - Lack of community } \\
\text { interest/low profile of } \\
\text { climate change issues } \\
\text { - Lack of stakeholder } \\
\text { coordination } \\
\text { - Out-dated funding and } \\
\text { investment models }\end{array}$ & $\begin{array}{l}\text { - Develop better understanding of the impact of the combined effects of ecosystem } \\
\text { change and eastward movement of the cropping zone } \\
\text { - Make use landscape configuration models and habitat matrices to assist effective } \\
\text { conservation in the face of landscape change } \\
\text { - Research into weed ecology, in particular population dynamics under changed } \\
\text { climatic regimes } \\
\text { - Build regional tourism resilience by reducing dependence on potentially vulnerable } \\
\text { single landscape features, changing focus to whole of landscape tourism } \\
\text { - Develop improved understanding by land managers and water professionals of the } \\
\text { relationship between soil health, storage of moisture in the soil profile and runoff } \\
\text { into rivers } \\
\text { - Limit vegetation fragmentation and impacts on landscape function from new human } \\
\text { settlements } \\
\text { - Encourage changes to the timing of use of natural resource-based tourism assets, } \\
\text { such as a shift from winter- to summer-based tourism for alpine areas } \\
\text { - Fund research into the impacts of climate change on the region's vulnerable } \\
\text { ecosystems. }\end{array}$ \\
\hline \multicolumn{3}{|l|}{ Regional infrastructure } \\
\hline $\begin{array}{l}\text { - Financial exposure to } \\
\text { infrastructure maintenance } \\
\text { costs }\end{array}$ & $\begin{array}{l}\text { - Poor placement of } \\
\text { infrastructure assets } \\
\text { - Ageing or inadequate }\end{array}$ & $\begin{array}{l}\text { - Strategically plan for local and regional infrastructure based on best available } \\
\text { climate change data. Infrastructure plans should consider emergency service } \\
\text { requirements and existing tolerance of structures and materials. }\end{array}$ \\
\hline
\end{tabular}




\begin{tabular}{|c|c|c|}
\hline $\begin{array}{l}\text { - Damage to roads restricting } \\
\text { tourism } \\
\text { - Emergency response and } \\
\text { healthcare services } \\
\text { - Safety risks to community. }\end{array}$ & $\begin{array}{l}\text { infrastructure } \\
\text { - Lack of resources and } \\
\text { inadequate funding to } \\
\text { upgrade or retrofit } \\
\text { assets } \\
\text { - Current policies on } \\
\text { beach protection }\end{array}$ & $\begin{array}{l}\text { - Undertake strategic exposure/risk audit of infrastructure assets to assess } \\
\text { importance in community service provision. Incorporate findings in reviews of asset } \\
\text { management plans and budgets } \\
\text { - Leverage the close connections between regional energy and road infrastructure } \\
\text { providers and local government to plan infrastructure maintenance and share } \\
\text { information. } \\
\text { - Close consultation and planning with Emergency Management (EM) in developing } \\
\text { new infrastructure and settlements. } \\
\text { - Assess the direct and indirect impacts of investing in new infrastructure on } \\
\text { - Ensystems. } \\
\text { natural disasters. } \\
\text { - Continue working with communities on savings programs to decrease demand for } \\
\text { energy and water. } \\
\text { - Support the continued evolution of engineering standards to incorporate tolerance } \\
\text { of future climate in developing new or retrofitting existing infrastructure. }\end{array}$ \\
\hline \multicolumn{3}{|l|}{ Community } \\
\hline $\begin{array}{l}\text { - Age structure of communities } \\
\text { - Stress related community } \\
\text { mental health } \\
\text { - Heat-related } \\
\text { illness/heatstroke, of the } \\
\text { most vulnerable in the } \\
\text { community } \\
\text { - Demands on healthcare and } \\
\text { emergency services and for } \\
\text { volunteers }\end{array}$ & $\begin{array}{l}\text { - Poor short term coping } \\
\text { - Skills } \\
\text { Declining social } \\
\text { networks and cohesion } \\
\text { in rural communities } \\
\text { - High expectations of } \\
\text { emergency service } \\
\text { provision } \\
\text { - Decline in EM volunteer } \\
\text { base } \\
\text { - 'Creeping' health } \\
\text { impacts } \\
\text { - Lack of personal and } \\
\text { community responsibility } \\
\text { for health. } \\
\text { - Patient flow to the ACT } \\
\text { - Ad hoc data sharing }\end{array}$ & $\begin{array}{l}\text { - Run multi-stakeholder, regional, community awareness programs about emergency } \\
\text { preparedness and local community cooperation } \\
\text { - Awareness programs to increase the community's short term coping ability to } \\
\text { weather-related extreme events } \\
\text { - Consider the ability of EM to service new communities and age care facilities in } \\
\text { land use planning } \\
\text { - Encourage a multi-stakeholder regional focus on emergency management } \\
\text { preparedness } \\
\text { - Emphasise community benefits of preventative health care to decrease reliance on } \\
\text { emergency services } \\
\text { - Employ indicators of health sector performance that report improvements to } \\
\text { primary health care rather than acute care, to demonstrate the importance of } \\
\text { - Dealthy lifestyles in reducing the demand on health services } \\
\text { acceptance of personal responsibility for one's own health and that of vulnerable } \\
\text { members of the community } \\
\text { - Ensure health care services undertake multi-stakeholder scenario planning for }\end{array}$ \\
\hline
\end{tabular}




\begin{tabular}{|l|l|l|}
\hline & $\begin{array}{l}\text { between jurisdictions } \\
\text { Poor cross-service } \\
\text { integration and planning }\end{array}$ & $\begin{array}{l}\text { extreme events } \\
\text { Develop a holistic services network providing multipurpose services drawn from the } \\
\text { pooled resources of a number of human service agencies } \\
\text { Establish formalised information sharing protocols on patient flow and servicing } \\
\text { across jurisdictions. }\end{array}$ \\
\hline
\end{tabular}




\section{Discussion}

Governments, in attempting to act on the issues of vulnerability and adaptation to climate change, are forced to grapple with the interactions of chaos, complexity and contradiction that increasingly make the management of social-ecological systems intractable. Some authors have dubbed this interplay of factors 'post-normal times' (for example Sardar, 2011). The concept of government as an adaptive entrepreneur attempting to balance multiple roles in a post-normal world requiring creative and flexible institutions (Hage et al., 2006) is apt but seldom achieved. IA has been proposed as a structured process that could assist government to more effectively integrate the social, economic, and environmental impacts of climate change in the development of adaptation policy (Lynch et al., 2008).

We believe the IRVA method demonstrates three advantages in comparison to other forms of vulnerability assessment as described by Smit and Wandel (2006). Firstly, the IRVA frames climate change as an issue of development and social equity rather than one of environmental pollution alone. Secondly, the IRVA utilises meta-analysis of sector-based information to integrate findings at regional scale. Thirdly, the information generated through the IRVA represents plural, conditional advice for policy formulation under uncertainty.

Burton et al. (2008) suggested that the framing of climate change as an environmental pollution issue is only partly correct and was distorting climate change policy. Their view that formulation of effective adaptation policy requires recognition also of climate change as an issue of development and social equity is borne out by our findings from the SE IRVA. Our process indicated that managers in many sectors are currently experiencing difficulty coping as a consequence of on-going demographic changes to regional populations (Gurren et al., 2005) and structural changes to regional economies (McColl and Young, 2005). For example, public sector managers identified changes in the age profile of local communities and in land use, declining ecosystem services, increasing exposure of regional infrastructure to inadequate funding models for renewal and maintenance, and the viability of local natural resource dependent industries as critical areas of regional vulnerability (Table 4). From our assessment of impacts, regional public sector managers believe that climate change will result in further impacts on these already vulnerable systems in the forms of resource conflicts between human settlements and the environment (particularly for water), increased energy costs, declining agricultural production and food security, and expansion of human settlements and the infrastructure that supports them.

Burton et al. (2008) identified meta-analysis as one of several, as yet, underutilised approaches that might facilitate a transformation of the way in which climate change is socially constructed. We believe our approach to the assessment of vulnerability and adaptive capacity is an example of the application of metaanalysis in climate change policy research. The use of the five capitals framework (Ellis, 2000) allows for the integration of findings across diverse sectors and for the spanning of administrative boundaries within which government agencies usually operate. Because human service agencies (such as health and housing) participated in the sectoral assessments alongside those responsible for environmental regulation and natural resources, issues of development and social equity were given equal consideration with the biophysical aspects of climate change.

We believe that the information generated through the IRVA represents plural, conditional advice for policy (Stirling, 2010). Plural, conditional methods eschew risk-based approaches to uncertainty that can result in single 'definitive' policy interpretations often favoured by decision-makers. Rather, the IRVA focuses on the complexity reflecting the uncertain predictions of future climate and the broad ranges of values, views and judgement of the participants. It also acknowledges that sectors (and communities) within regions may follow a range of development paths into the future, that there is no single, correct path and that the sectors 
involved in the analysis may not reach consensus on what constitutes an effective climate change response (for example, pathways that lead to security of the agriculture sector may be in conflict with those aimed at protection of some ecosystem services in the face of climate change). Areas of potential criticism of the IRVA lie in the doubt surrounding the readiness of policy-makers to accept plural, conditional advice and their ability to enter into innovative planning approaches to adaptation based on such advice (Doubleday and Wilsdon, 2012; National Research Council, 2012). Nevertheless, the comprehensive list of actions identified through the IRVA to address constraints to adaptation would mesh well with the implementation of an Assumption-Based Planning approach. Walker et al. (2013) outlined four guiding principles for the design of a sustainable adaptive plan under deep uncertainty as developed through Assumption-Based Planning. These principles are to: explore a wide variety of relevant uncertainties, connect short-term targets to longterm goals over time, commit to short-term actions while keeping options open, and continuously monitor the world and take actions if necessary. Such an approach would likely involve sequencing the implementation of actions over time so that adaption co-evolves with dynamic climate, social, economic and biophysical conditions, and leaves open a range of future adaptation pathways.

The prevailing view among participants, in particular those representing local government, was that control of the financial resources needed to implement action on climate change lies outside of the region (Figure 4). This is supported by independent reviews of local government sustainability in Australia (Allan, 2010) that found one in four councils were financially unsustainable in the long-term without substantial rate increases and/or disruptive expenditure cuts. Restoration, maintenance and renewal of public infrastructure, which the IRVA identified as essential to cope with climate change, was severely underfunded. Given the lack of financial autonomy at regional scale and the complex interconnections among the sectors, it is clear that consideration of future climate impacts on a single sector in isolation from the matrix of actions government must take to foster adaptation to climate change (Table 4) is unlikely to be successful and could lead to significant duplication of effort assuming sufficient human and financial resources could be found to implement adaptation actions.

Pelling (2011) proposed a conceptual model of adaptation to hazards as following one of three pathways: resilience, transition or transformation. These pathways lie on a spectrum of change depending on the degree to which adaptation supports an existing system's structure and function (resilience), fosters reform within existing governance regimes (transition) or enables more fundamental processes of change in governance or social reform (transformation). We classified the suggested actions identified through the IRVA shown in Table 4 according to Pelling's framework of vulnerability reduction (Figure 5). Almost twothirds of the adaptation actions suggested by participating public sector managers would contribute to regional resilience through maintenance of the status quo (Handmer and Dovers, 1996), with improvements to strategic planning, resource use, training and communication dominating the list. A smaller number of actions, slightly less than one-third, were considered more likely to lead to transition as they appeared to address some of the fundamental assumptions about the future of the SE Region. Most commonly these actions called for processes to incentivise change leading to more rapid agricultural adjustment, building of regional and local social capital and greater protection of ecosystem services. Actions that would likely lead to regional transformation were limited. However, the adoption of two actions related to improved resource use (networking of regional water supplies and employment of landscape configuration models to regulate landscape change) stood out as requiring fundamental changes to the current governance of regional natural resources. A third action called for policies to stimulate greater acceptance of preventative health care and personal responsibility for community health. This action was aimed at reducing reliance on already over-extended government services and would require transformative change in community values (Lomas, 1998). 


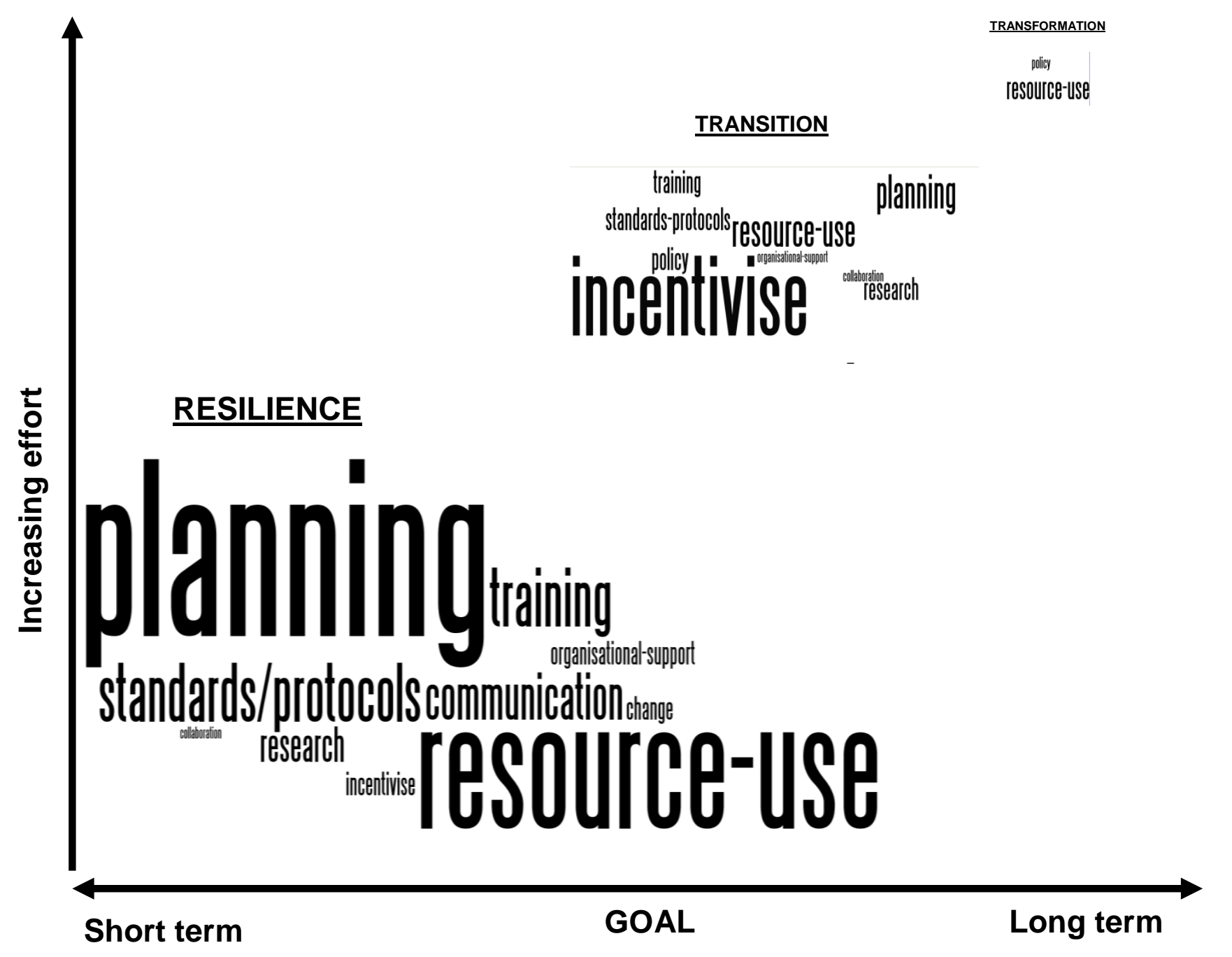

Figure 5. Scope and scale of climate change adaptation depicted as a word-cloud based on a list of suggested adaptation actions assembled by pooling information from all sector workshops and assigning each action to a resilience, transition or transformation framework (after Pelling 2011). The area of the figure occupied by each category reflects the number of actions attributed to it, and the size of the label within each category reflects the frequency with which the option occurred. (Adapted from Moser and Eckstrom 2010).

\section{Conclusion}

The use of an IA approach in the SE IRVA, which involved input from local experts, proved to be a successful technique because it is place-based, considers multiple interacting stresses, examines differential adaptive capacity, and was prospective as well as historical (Schroeter et al., 2005). In addition it promoted a complex systems approach to understanding climate impacts; it encouraged networking among participants from all tiers of government and across a range of sectors; it elicited tacit knowledge about local conditions and shadow systems (Pelling, 2011) that would not have been discovered otherwise; and, it generated enthusiasm among local participants for the future development of a regional adaptation plan.

The assessment of vulnerability is intended to be an initial step in a longer-term process of regional adaptation planning. The success of this process has led to further IRVAs in other regions in NSW; at time of writing an assessment of the Riverina-Murray Region has been completed and assessments of the North Coast of NSW and of the City of Sydney are planned for completion in 2013. 


\section{References}

Adger, N., Dessai, S., Goulden, M., Hulme, M., Lorenzoni, I., Nelson, D., Naess, L., Wolf, J. and Wreford, A. (2009), "Are there social limits to adaptation to climate change?", Climatic Change, Vol. 93, No. 3/4, pp. 335-354.

Allan, P. (2010), "Progress on local government sustainability since the 2006 inquiry", National Local Government Asset Management and Public Works Engineering Conference, Melbourne, May 12th 2010, available at: www.mav.asn.au/policy-services/transport-infrastructure/assetmanagement/Related\%20documents\%20\%20asset\%20management/NSW\%20local\%20government\%20 sustainability.ppt (accessed 9 July, 2012).

Augier, M. and Vendelo, M. (1999), "Networks, cognition and management of tacit knowledge", Journal of Knowledge Management, Vol. 3, No. 4, pp. 252-261.

Australian Bureau of Statistics (ABS) (2008), The 2006 Census, available at: http://abs.gov.au/websitedbs/censushome.nst/home/historicalinformation2006?opendocument\&navpos=3 $\underline{20}$ (accessed 9 July, 2012).

Bostrom, A., Morgan, M. G., Fischhoff, B., and Read, D. (1994), "What do people know about global climate change? 1. Mental models", Risk Analysis, Vol. 14, No. 6, pp. 959-970.

Brooks, M., Gagnon-Lebrun, F., Harvey, H. and Sauve, C. (2009), "Prioritizing Climate Change Risks and Actions on Adaptation. A Review of Selected Institutions, Tools, and Approaches. Final Report March 2009", Policy Research Initiative, Government of Canada, available at: www.horizons.gc.ca/2009-0007eng.pdf (accessed 12 March, 2012).

Brown, P. R., Nelson, R., Jacobs, B., Kokic, P., Tracey, J., Ahmed, M. and DeVoil, P. (2010), "Enabling natural resource managers to self-assess their adaptive capacity", Agricultural Systems, Vol. 103, No. 8, pp. 562-568.

Burton, I., Dickinson, T. and Howard, Y. (2008), "Up scaling adaptation studies to inform policy at the global level”, The Integrated Assessment Journal, Vol. 8, No. 2, pp. 25-37.

Busch P (2004) Knowledge management implications of articulable tacit knowledge: case studies on its diffusion, PhD Thesis, Macquiarie University, Sydney.

Cash, D., Adger, W., Berkes, F., Garden, P., Lebel, L., Olsson, P., Pritchard, L. and Young, O. (2006), "Scale and cross-scale dynamics: governance and information in a multilevel world", Ecology and Society, Vol. 11, No. 2, pp. 8-19.

Collins, H. and Evans, R. (2002), "The third wave of science studies: studies of expertise and experience", Social Studies of Science, Vol. 32, No. 2, pp. 235-296.

Department of Environment, Climate Change and Water NSW (2010), NSW Climate Impact Profile: The impacts of climate change on the biophysical environment of New South Wales, available at: www.environment.nsw.gov.au/climatechange/RegionallmpactsOfClimateChange.htm (accessed 11 April 2012).

de la Vega-Leinert, A. and Schroter, D. (2009), "Evaluation of a stakeholder dialogue on European vulnerability to global change", in Patt, A., Schroter, D., Klein, R. and de la Vega-Leinert, A. (Eds), Assessing vulnerability to global environmental change: making research useful for adaptation decision making and policy, Eathscan, London, UK, pp. 195-214. 
Doubleday, R. and Wilsdon, J. (2012) "Science policy: beyond the great and good”, Nature, Vol. 485, No. 7398, pp. 301-302.

Ellis, F. (2000), Rural Livelihoods and Diversity in Developing Countries, Oxford University Press, Oxford, UK.

Fankhauser, S., Smith, J. and Tol, R. (1999), "Weathering climate change: some simple rules to guide adaptation decisions", Ecological Economics, Vol. 30, No. 1, pp. 67-78.

Fowler H., Blenkinsop, S. and Tebaldi, C. (2007), "Linking climate change modelling to impacts studies: recent advances in downscaling techniques for hydrological modelling", International Journal of Climatology, Vol. 27, No. 12, pp. 1547-1578.

Fox J. (2001), "Vertically integrated policy monitoring: A tool for civil society policy advocacy", Nonprofit and Voluntary Sector Quarterly, Vol. 30, No. 3, pp. 616-627.

Froy, F. and Giguère, S. (2010), "Breaking out of policy silos: doing more with less", available at: www.oecdilibrary.org/urban-rural-and-regional-development/breaking-out-of-policy-silos 9789264094987-en (accessed 20 November, 2012).

Giampietro, M. (2002), “Complexity and scales: the challenge for Integrated Assessment”, Integrated Assessment, Vol. 3, No. 2-3, pp. 247-265.

Gertler, M. (2003), "Tacit knowledge and the economic geography of context, or the undefinable tacitness of being (there)", Journal of Economic Geography, Vol. 3, No. 1, pp.75-99.

Gomiero, T., Giampietro, M. and Mayumi, K. (2006), "Facing complexity on agro-ecosystems: a new approach to farming system analysis", International Journal of Agricultural Resources, Governance and Ecology, Vol. 5, No. 2/3, pp. 116-144.

Gurran, N., Squires, C. and Blakely, E. (2005), "Planning for Sea Change in Coastal Australia”, Australian Planner, Vol. 42, No. 4, pp. 10-11.

Hage, M., Leroy, P. and Willems, E. (2006) "Participatory Approaches in Governance and in Knowledge Production: What Makes the Difference?" Working Paper Series 2006/3, Research Group Governance and Places, Radbound University Nijmegen, The Netherlands.

Handmer, J. and Dovers, W. (1996), "A typology of resilience: rethinking institutions for sustainable development", Organization and Environment, Vol. 9, No. 4, pp. 482-511.

Hartel, C. and Pearman, G. (2010), "Understanding and responding to the climate change issue: towards a whole-of-science research agenda", Journal of Management \& Organization, Vol. 16, No. 1, pp. 16-47.

IPCC (2008), "Glossary of Terms for Working Groups II", available at: www.ipcc.ch/pdf/glossary/ar4wg2.pdf (accessed 16 March, 2012).

Ison, R. (2010), Systems Practice: How to Act in a Climate-Change World, Springer, London, UK.

Janasoff, S. (2003), "Breaking the waves in science studies: Comment on H.M. Collins and Robert Evans, 'The Third Wave of Science Studies'”, Social Studies of Science, Vol. 33, No. 3, pp. 389-400.

Leith, P., Jacobs, B., Brown, P.R. and Nelson, R. (2012), "A participatory assessment of NRM capacity to inform policy and practice. Cross-scale evaluation of enabling and constraining factors", Society and Natural Resources, Vol. 25, No. 8, pp. 775-793.

Li, G. M. (2010), A Methodology for Integrated Assessment of Climate Change Impacts on Urban 
Settlements (IACCIUS) in Australia, available at http://fennerschool-

research.anu.edu.au/iaccius/publications/reports/IACCIUS Methodology Report Li 2010.pdf (accessed 20 November, 2012).

Lomas, J. (1998), "Social capital and health: implications for public health and epidemiology", Social Science and Medicine, Vol. 47, No. 9, pp. 1181-1188.

Loria, M. (2008), "A review of the main approaches to knowledge management", Knowledge Management Research and Practice, Vol. 6, No. 1, pp. 77-89.

Lynch, A., Tryhorn, L. and Abramson, R. (2008), "Working at the boundary: facilitating interdisciplinarity in climate change adaptation research", American Meteorological Society, Vol. 89, No. 2, pp. 169-179.

Malone, E. and Engle, N. (2011), "Evaluating regional vulnerability to climate change: purposes and methods”, Wiley Interdisciplinary Reviews: Climate Change, Vol. 2, No. 3, pp. 462-474.

McColl, J. and Young, M. (2005) Managing Change: Australian structural adjustment lessons for water, available at: http://uat.pc.gov.au/ data/assets/pdf file/0010/91000/sub005-attachment4.pdf (accessed 20 November 2012).

Melanson, G. (1999), "Considering complexity", Annals of the Association of American Geographers, Vol. 89, No. 4, pp. 746-753.

Milne, B. (1998), "Motivation and Benefits of Complex Systems Approaches in Ecology", Ecosystems, Vol. 1, No. 5, pp. 449-456.

Moser, S. and Eckstrom, J. (2010) "A framework to diagnose barriers to climate change adaptation", Proceedings of the National Academy of Sciences of the United States of America, Vol. 107, No. 51, pp. 22026-22031.

National Research Council (2012), Using Science as Evidence in Public Policy, National Academies Press, Washington, DC.

Nerlich, B. (2010), “'Climategate': paradoxical metaphors and political paralysis”, Environmental Values, Vol. 19, No. 4, pp. 419-442.

Nonaka, I. and von Krogh, G. (2009), "Tacit knowledge and knowledge conversion: controversy and advancement in organizational knowledge creation theory", Organization Science, Vol. 20, No, 3, pp. $635-652$.

Patt, A., Klein, R. and de la Vega-Leinert, A. (2005), "Taking the uncertainty in climate-change vulnerability assessment seriously", Comptus Rendus Geoscience, Vol. 337, No. 4, pp. 411-424.

Pelling, M. (2011), Adaptation to climate change: from resilience to transformation, Routledge, London, UK.

Quentin Grafton, R. (2010), "Adaptation to climate change in marine capture fisheries", Marine Policy, Vol. 34, No. 3, pp.606-615.

Rayner, S. (2010), "How to eat an elephant: a bottom-up approach to climate policy", Climate Policy, Vol. 10, No. 6, pp. 615-621.

Rayner, S. and Malone, E. (1998), "Ten Suggestions for Policymakers", in Rayner, S. \& Malone, E. (Eds), Human Choice and Climate Change, Vol. 4, What Have We Learned, Battelle Press, Columbus, Ohio, pp. 109-138.

Reibsame, W. (1990), "Anthropogenic climate change and a new a paradigm of natural resource planning", 
Professional Geographer, Vol. 42, No. 1, pp.1-12.

Ribot, J. (1995) "The causal structure of vulnerability: its application to climate impact analysis", GeoJournal Vol. 35, No. 2, pp. 119-122.

Rindfuss, R., Entwisle, B., Walsh, S., An, L., Badenoch, N., Brown, D., Deadman, P., Evans, T., Fox, J., Geoghegan, J., Gutmann, M., Kelly, M., Linderman, M., Liu, J., Malanson, G., Mena, C., Messina, J., Moran, E., Parker, D., Parton, W., Prasartkul, P., Robinson, D., Sawangdee, Y., Vanwey, L. and Verburg, P. (2008), "Land use change: complexity and comparisons", Journal of Land Use Science, Vol. 3, No. 1, pp. $1-10$.

Rotmans, J. (1998), "Methods for IA: the challenges and opportunities ahead", Environmental Modeling and Assessment, Vol. 3, No. 3, pp. 155-179

Sardar, Z. (2010), "Welcome to postnormal times”, Futures, Vol. 42, No. 5, pp. 435-444.

Scarlett, L. (2011), "Climate adaptation: science and collaborative decision making”, in Linkov, I. and Bridges, T. (Eds), Climate: Global Change and Local Adaptation, Springer, Dordrecht, The Netherlands, pp. 9-17.

Schroeter, D., Polsky, C. and Patt, A. (2005), "Assessing vulnerabilities to the effects of global change: An eight step approach" Mitigation and Adaptation Strategies for Global Change, Vol.10, No.4, pp. 573-596.

Shachter, R. (1986), "Evaluating influence diagrams”, Operations Research, Vol. 34, No. 6, pp. 871-882.

Smit, B. and Wandel, J. (2006), "Adaptation, adaptive capacity and vulnerability", Global Environmental Change, Vol. 16, No. 3, pp. 282-292.

Stirling, A. (2010), "Keeping it complex", Nature, Vol. 468, No. 7327, pp. 1029-1031.

Vignola, R., Locatelli, B., Martinez C. and Imbach, P. (2009), "Ecosystem-based adaptation to climate change: what role for policy-makers, society and scientists?", Mitigation and Adaptation Strategies for Global Change, Vol. 14, No. 8, pp. 691-696.

Wachinger, G., Renn, O., Begg, C. and Kuhlicke, C. (2012), "The risk perception paradox - implications for governance and communication of natural hazards”, Risk Analysis, Vol. 33, No. 6, pp. 1049-1065.

Walker, W., Haasnoot, M. and Kwakkel, J. (2013), "Adapt or perish: A review of planning approaches for adaptation under deep uncertainty", Sustainability, Vol. 5, No. 3, pp. 955-979.

Weaver, C. Lempert, R., Brown, C., Hall, J., Revell, D. and Sarewitz, D. (2013), "Improving the contribution of climate model information to decision making: the value and demands of robust decision frameworks", Wiley Interdisciplinary Reviews: Climate Change, Vol. 4, No. 1, pp.39-60. 